Article

\title{
Technical Efficiency in the Agricultural Business-The Case of Slovakia
}

\author{
Jarmila Lazíková ${ }^{1, *}$, Zuzana Lazíková ${ }^{1}$, Ivan Takáč ${ }^{2}$ (D), L'ubica Rumanovská ${ }^{2}$ and \\ Anna Bandlerová 1 \\ 1 Department of Law, Slovak University of Agriculture in Nitra, 94976 Nitra, Slovakia; \\ xlazikova@uniag.sk (Z.L.); anna.bandlerova@uniag.sk (A.B.) \\ 2 Department of European Policies, Slovak University of Agriculture in Nitra, 94976 Nitra, Slovakia; \\ ivan.takac@uniag.sk (I.T.); lubica.rumanovska@uniag.sk (L'.R.) \\ * Correspondence: jarmila.lazikova@uniag.sk
}

Received: 9 September 2019; Accepted: 4 October 2019; Published: 11 October 2019

\begin{abstract}
The key element of the European Union (EU) Common Agricultural Policy is sustainable agriculture where the social, economic, and environmental objectives should be fulfilled. This role can fulfill only those agricultural holdings that are effective in the transformation of inputs to outputs, and which do not waste the inputs. Therefore, we analyze the technical efficiency of the agricultural holdings in the Slovak regions, and try to identify the factors that are able to influence the efficiency of agricultural holdings. We can conclude that there are regional disparities in technical efficiency in Slovakia; however, the problem of inefficiency is not typical only for the agricultural holdings in the areas with natural constraints. These regional disparities should be considered when adopting a new political measure to support sustainable agriculture. By the results of econometric models, we find that the agricultural production diversity, the policy of the labor market, and tax policy are the important factors influencing the technical efficiency of the agricultural holdings in Slovakia.
\end{abstract}

Keywords: agricultural business; technical efficiency; regional disparities; agricultural production diversity

\section{Introduction}

In the 21st century, agriculture is still a basic instrument in the fight against poverty and sustainable development. The main role of agriculture consists of economic activities, environmental services, and livelihood [1]. International organizations, policymakers, national governments, and local institutions are interested in sustainable agriculture, and they consider it as one of the most important objectives [2]. Sustainable agriculture is a core issue of the 2030 Agenda and the first step to eliminating hunger. In the 2030 Agenda, all sectors, including agriculture, are considered from the economic, social, and environmental dimension of sustainability [3]. Sustainable agriculture has to ensure the needs of living and future generations as well as profitability, environmental health, and equity [3]. It is also a core objective for the European Union in its amended Common Agricultural Policy [4], which is one of the largest agricultural policies of the world. It was focused primarily on the support of agricultural production and farm income; nowadays, the Common Agricultural Policy (CAP) integrates instruments to support the environmental and societal challenges, but the overall set of objectives remains incoherent and unbalanced [5-7]. The European Commission [8] argued that the economic, ecologic, or social objectives of sustainable agricultural and rural development do not support always each other, and they compete with each other. In this case, the sustainability is related to the need to find the balance among these elements [8]. Astier et al. [9] added that we need agricultural sustainability focused on the improvement of current systems and practices, mainly in the context of natural 
resource management. The core component for improving agricultural sustainability is measuring farm sustainability [10]. De Koeijer et al. [11] argue that increasing the output per unit of input reduces environmentally harmful emissions and increases income by reducing costs or increasing output [11]. In addition, improving the end-use efficiency of resources is necessary, regardless of renewable or non-renewable resources [12]. However, efficiency is only a precondition for resource use that should be ethically acceptable, because inefficiency tends to waste [13]. Then, efficiency is necessary but not sufficient for the fairness that is embodied in the concept of sustainability, but efficiency increasing may result in a sustainability improvement [14-16]. In our paper, we try to calculate the efficiency of the agricultural holdings in Slovakia to identify how the agricultural holdings are effective in the transformation of inputs to outputs in the particular regions of the country, and to identify the factors that are able to influence the technical efficiency.

\section{Literature Overview}

Since Charnes, Cooper, and Rhodes [17] have created the non-parametric technique of data envelopment analysis, there are many studies and papers trying to evaluate the efficiency and productivity in the various fields of the economy, including agricultural holdings [18-23] or holdings in the food industry [24]. Since 1978 up through the year 2009, around 4500 Data Envelopment Analysis (DEA) related papers, both theoretically and practically oriented, have been published in the ISI Web of Science database [25]. In addition to this collection, around 2000 papers have been published in the same database during the period from 2010 to 2014 [26].

According to our objective, we wanted to find the papers interested in the efficiency of the agricultural holdings. Most of the studies are from Asiatic countries, e.g., [27-30]. In Europe, Burja [31] showed that the poor performance of agriculture in Romania and the efficiency recorded at the level of the development regions varies. Baráth and Fertó [32] investigate the relative productivity levels and decompose productivity change for European agriculture between 2004-2013. Cuerva [33] confirms that agricultures move very close to their stationary states, which differ among themselves, in such a way that productivity differences will persist in the long term. Ezcurra et al. [34] reveals a decrease in regional agricultural productivity disparities, while intra-distribution mobility is found to be relatively limited during the study period. Galluzzo [18] pointed out that specialized Bulgarian farms have had higher levels of technical efficiency compared to mixed farms, and financial subsidies allocated by the CAP have had a positive impact toward farmers, both increasing the technical efficiency and also reducing the socio-economic marginalization of Bulgarian rural areas. Marongiu et al. [35] focused on the efficiency of the Italian and French dairy farms situated in the Alps. Munroe [36] conducted a survey of economic efficiency in southern agriculture to understand why small-scale farming in Poland is inefficient, despite longstanding secure property rights. In Slovakia, the efficiency of agricultural holdings is a subject matter of several authors, e.g., [37-39]. They focused on the relationship between the efficiency of the agricultural holdings and their legal forms, size, number of employees, or acreage of agricultural land. Sojková et al. [40] focused on the comparison of the efficiency of agricultural holdings between the agricultural holdings from the production regions and the agricultural holdings from the less favored areas. However, they analyzed the comparison by the stochastic frontier analysis, and they recommended comparing the results also by DEA analysis. Based on this review, we try to use DEA analysis to compare the efficiency of agricultural holdings in the particular Slovak regions, and moreover to identify the factors that are able to influence the technical efficiency. Our paper is organized as follows: firstly, we try to calculate the efficiency of the agricultural holdings in Slovakia by the DEA analysis; secondly, we try to find out if there are regional disparities in the efficiency of the agricultural holdings among the administrative classification (regions (NUTS III) and districts (LAU 1) in Slovakia) and among the agricultural classification of Slovakia (according to the production regions 1 to 5 defined below). Thirdly, we try to identify the factors that are able to influence the technical efficiency. 


\section{Data and Methods}

We use data collected by the Ministry of Agriculture and Rural development of Slovak Republic among the agricultural holdings in 2015 and 2016. The ministry provided us data about 913 agricultural holdings; of it, only 744 were used, because 169 agricultural holdings were excluded due to zero revenues for their goods and services. Therefore, we interviewed some more agricultural holdings from the regions (districts) with the missing data. We received together 1109 agricultural holdings, of which there were 582 agricultural business companies, 232 agricultural cooperatives, and 295 individual farmers.

The technical efficiency of agricultural holdings was evaluated by the non-parametric input-oriented BCC DEA model proposed by Banker et al. [41]. This model is expressed as follows:

$\min \theta$

subject to:

$$
\begin{gathered}
Y \times \lambda \geq y_{i} \\
-\theta \times x_{i}+X \times \lambda \leq 0 \\
1^{T} \times \lambda=1 \\
\lambda \geq 0
\end{gathered}
$$

where $y_{i}=\left(y_{1}, \ldots, y_{m}\right)$ is a vector of $\mathrm{m}$ outputs, $x_{i}=\left(x_{1}, \ldots, x_{k}\right)$ is a vector of $\mathrm{k}$ inputs for each of these agricultural holdings, $Y(\mathrm{n} \times \mathrm{m})$ is a matrix of $\mathrm{m}$ outputs of each from the $\mathrm{n}$ agricultural holdings, $X(\mathrm{n} \times \mathrm{k})$ is a matrix of $\mathrm{k}$ inputs of each from the $\mathrm{n}$ agricultural holdings, $\theta$ is a scalar, and $\lambda$ is a $\mathrm{I} \times 1$ vector of constant. The value $\theta$ is the efficiency score for the $i$-th agricultural holding. $\theta$ is from the interval $<0,1>$, and a value 1 indicates a point on the frontier and a technically efficient farm. If $\theta<0$, then $\theta$ stipulates how much the evaluated agricultural holding should reduce its inputs to be effective in the output production. The convexity constraint $1^{T} \times \lambda=1$ enables modifying the CRS (constant returns to the scale) model for the VRS model (variable returns to the scale), because the agricultural holdings have had different sizes related to the acreage of land or number of employees. The model deals with the four inputs (land in ha; capital assets in EUR; average number of employees; costs

\begin{tabular}{|c|c|c|c|c|}
\hline & Average & Standard Deviation & Minimum & Maximum \\
\hline \multicolumn{5}{|c|}{ Input } \\
\hline capital assets $(€)$ & $1,328,276.44$ & $3,388,517.80$ & 180.00 & $64,146,334.00$ \\
\hline land (ha) & 693.33 & 862.88 & 2.35 & 5834.20 \\
\hline average number of employees & 15.37 & 26.45 & 0.00 & 236.00 \\
\hline $\begin{array}{c}\text { costs for materials. energy and } \\
\text { services }(€)\end{array}$ & $659,207.97$ & $1,160,747.17$ & 33.00 & $16,911,140.00$ \\
\hline \multicolumn{5}{|c|}{ Output } \\
\hline revenues for goods and services $(€)$ & $803,329.20$ & $1,556,413.55$ & 280.00 & $25,915,578.00$ \\
\hline
\end{tabular}
for materials, energy, and services in EUR) and one output (revenues for goods and services in EUR) (Table 1).

Table 1. Inputs and outputs descriptive statistics.

We identify the statistical significant differences among the regions according to the administrative classification (NUTS III) and the regions according to the agricultural classification of Slovak country (1-maize production area; 2 - sugar beet production area; 3 - potato production area; 4 - potato-oat production area; 5-mountain production area) by the Kruskal-Wallis test and multiple range tests available in the programme Statgraphics Plus. The Kruskal-Wallis test was characterized as follows: 


$$
H=\left(\frac{12}{N(N+1)} \times \sum_{j=1}^{k} \frac{R_{j}^{2}}{n_{j}}\right)-3 \times(N+1)
$$

H-Kruskal-Wallis test characteristics

$\mathrm{N}$-total number of agricultural holdings (all regions combined)

$R_{j}$-rank total for each region

$N_{j}$-number of agricultural holdings in each region

$k$-number of regions

In the next step, we calculate the agricultural production diversity of each agricultural holding by the Shannon's equitability index, which is expressed as [42]:

$$
H=-\sum_{i=1}^{s} p_{i} \ln \left(p_{i}\right)
$$

where $s$ is number of agricultural products and $p_{i}$ is the proportion of amount of one particular species (n) divided by the total amount of agricultural production $(\mathrm{N})$. The Shannon's equitability index (EH) is computed as:

$$
E_{H}=\frac{H}{H_{\max }}
$$

where $H$ is the Shannon's diversity index, and $H_{\max }$ is calculated as $\ln (\mathrm{s})$. Shannon's equitability index assumes a value between $0-1$, with 1 being complete evenness. In Slovakia, most of the agricultural holdings are focused on the mixed (crop and animal) production. The most favored crops are cereals (wheat, barley, maize), fodder crops, and industrial crops, e.g., [43,44]. The most favored animal production is beef meat, milk, pig meat, sheep meat, poultry, and eggs, e.g., [45].

At last, we try to identify the factors that are able to influence the technical efficiency by using the OLS and TOBIT model, because of censured dependent variable bordered by 0 and 1 . We were able to use only data from the ministry due to missing several data of interviewed agricultural holdings. From 744 agricultural holdings, only 683 of them were integrated in the models. The rest of them were excluded from various reasons (e.g., mistakes in the data, missing some of the data, or the data were outliers). The econometric software GRETL was used. The heteroskedasticity was tested by the Breusch-Pagan test. The linear regression model is expressed as:

$$
y_{j}=\alpha+\beta_{1} x_{1 j}+\beta_{2} x_{2 j}+\beta_{3} x_{3 j}+\beta_{4} x_{4 j}+\beta_{5} x_{5 j}+\beta_{6} x_{6 j}+\gamma x+\varepsilon_{j}
$$

where $y_{j}$ is the technical efficiency of agricultural holding $j$ as a dependent variable; $\alpha$ is the intercept; $x_{1 j}$ is Shannon's equitability index of an agricultural holding; $x_{2 j}$ is a single farm payment (SAPS); $x_{3 j}$ is a payment for greening; $x_{4 j}$ is a payment for less favorite areas called areas with natural constraints (ANC); $x_{5 j}$ is an agri-environmental scheme payments (AES); $x_{6 j}$ is a payment for animal welfare (WELFARE); $\beta_{1}$ expresses how many percentage points the technical efficiency changes if Shannon's equitability index increases by one percentage point; $\beta_{2}$ to $\beta_{6}$ expresses how many percentage points the technical efficiency changes if a particular payment increases by 1 euro; $x$ is a vector of the control variables in the model with particular regression coefficients expressed as vector $\gamma$; and $\varepsilon_{j}$ are residuals that are independent and identically distributed. The vector of control variables consists of independent (explanatory) variables that include the distance from the city, labor costs, total revenues share in total costs, revenues from the animal production share in revenues of the agricultural production, number of members, number of new jobs, rent payment for 1 ha of agricultural land, land taxes, share of property taxes in total costs, ANC land, irrigated agricultural land, region, production area, and membership in the farmers' associations. The descriptive statistics of the mentioned variables are shown in Table 2. 
Table 2. Statistics of the variables integrated into the econometric models. ANC: areas with natural constraints.

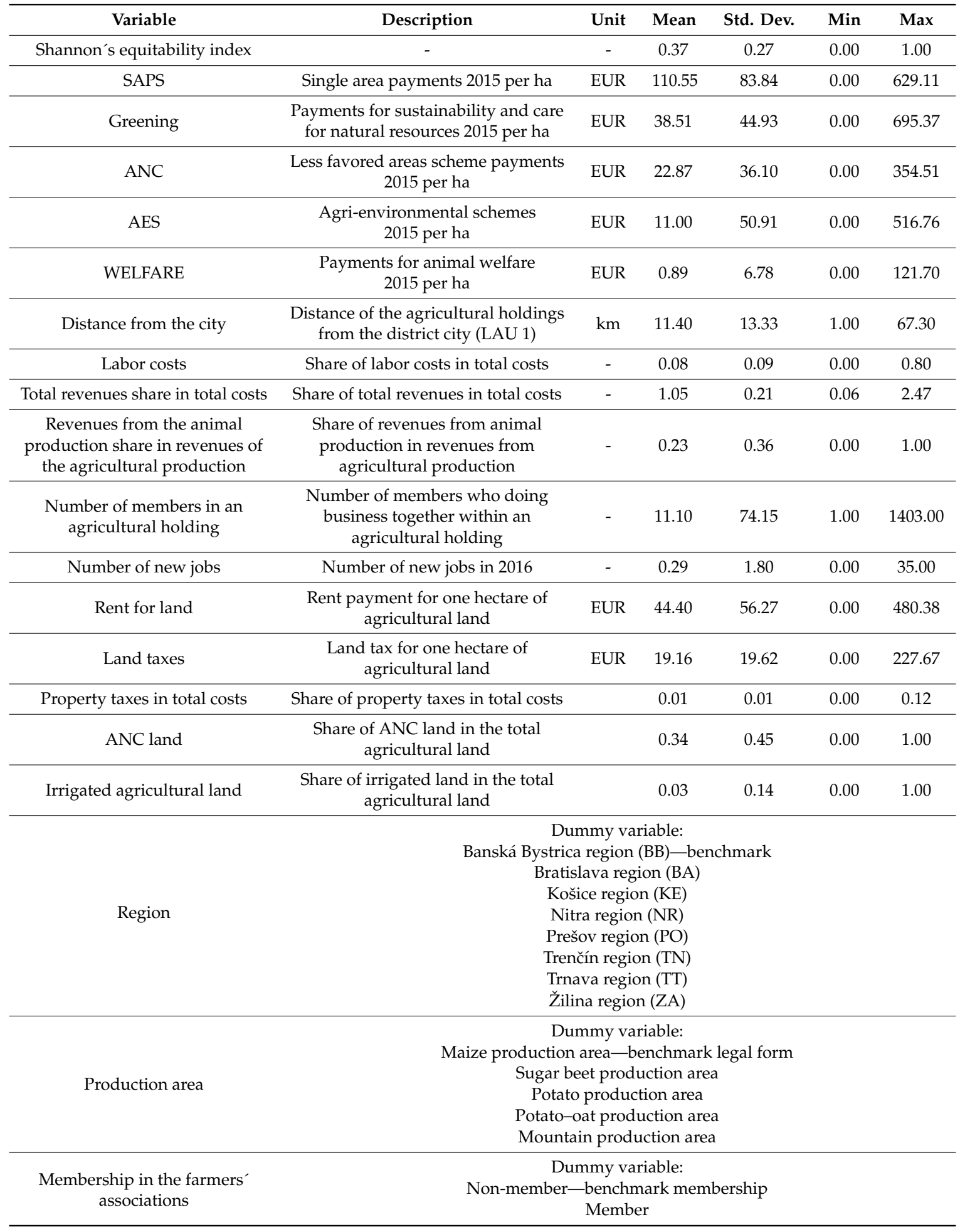

We take into account the CAP payments for 2015 to find out the impact on the technical efficiency in 2016, because we assume that the CAP payments paid on the end of the particular year have a stronger impact on the technical efficiency in the next year than the CAP payments paid on the end of the year when technical efficiency was calculated. 


\section{Results}

\subsection{Technical Efficiency of Agricultural Holdings}

We estimate the technical efficiency of agricultural holdings by DEA input-orientation model with the aim to minimize inputs given the output. We use the EMS software (Efficiency Measurement System) to calculate the relevant technical efficiency. The technical efficiency scores for 1109 agricultural holdings were distributed into the regions (NUTS III), districts (LAU 1), and production areas. We analyzed firstly the administrative classification by the regions and districts, and the results are presented in Table 3. The administration units are characterized by the geometric mean, maximum, and minimum of technical efficiency scores. We used the geometric mean, because it is less influenced by the outliers than the arithmetic mean.

Table 3. Efficiency scores of agricultural holdings in the regions (NUTS III) and the districts (LAU 1).

\begin{tabular}{|c|c|c|c|c|c|c|c|}
\hline Region & $\begin{array}{l}\text { Geomean } \\
\text { TE VRS }\end{array}$ & $\begin{array}{l}\text { Max TE } \\
\text { VRS }\end{array}$ & $\begin{array}{l}\text { Min TE } \\
\text { VRS }\end{array}$ & District & $\begin{array}{l}\text { Geomean } \\
\text { TE VRS }\end{array}$ & $\begin{array}{l}\text { Max TE } \\
\text { VRS }\end{array}$ & $\begin{array}{l}\text { Min TE } \\
\text { VRS }\end{array}$ \\
\hline \multirow{13}{*}{$\begin{array}{c}\text { Banská Bystrica } \\
\text { region }\end{array}$} & & \multirow{13}{*}{$100.00 \%$} & \multirow{13}{*}{$2.29 \%$} & Žiar nad Hronom $(\mathrm{ZH})$ & $16.18 \%$ & $63.16 \%$ & $5.52 \%$ \\
\hline & & & & Krupina (KA) & $19.97 \%$ & $61.30 \%$ & $6.04 \%$ \\
\hline & & & & Žarnovica (ZC) & $9.27 \%$ & $100.00 \%$ & $2.29 \%$ \\
\hline & & & & Banská Bystrica (BB) & $25.98 \%$ & $60.37 \%$ & $13.83 \%$ \\
\hline & & & & Revúca (RA) & $28.15 \%$ & $43.20 \%$ & $12.36 \%$ \\
\hline & & & & Banská Štiavnica (BS) & $33.79 \%$ & $59.71 \%$ & $22.22 \%$ \\
\hline & & & & Poltár (PT) & $28.48 \%$ & $72.83 \%$ & $7.02 \%$ \\
\hline & & & & Rimavská Sobota (RS) & $33.55 \%$ & $100.00 \%$ & $7.96 \%$ \\
\hline & & & & Brezno (BR) & $32.41 \%$ & $91.59 \%$ & $7.34 \%$ \\
\hline & & & & Lučenec (LC) & $34.15 \%$ & $100.00 \%$ & $2.54 \%$ \\
\hline & & & & Zvolen (ZV) & $44.62 \%$ & $87.97 \%$ & $22.54 \%$ \\
\hline & & & & Vel'ký Krtíš (VK) & $42.18 \%$ & $82.98 \%$ & $5.68 \%$ \\
\hline & & & & Detva (DT) & $49.78 \%$ & $62.42 \%$ & $39.50 \%$ \\
\hline \multirow{4}{*}{$\begin{array}{l}\text { Bratislava } \\
\text { region }\end{array}$} & \multirow{4}{*}{$49.01 \%$} & \multirow{4}{*}{$100.00 \%$} & \multirow{4}{*}{$1.39 \%$} & Pezinok (PK) & $45.89 \%$ & $74.75 \%$ & $25.12 \%$ \\
\hline & & & & Bratislava (BA) & $40.68 \%$ & $100.00 \%$ & $1.39 \%$ \\
\hline & & & & Malacky (MA) & $67.69 \%$ & $100.00 \%$ & $34.25 \%$ \\
\hline & & & & Senec (SC) & $68.64 \%$ & $100.00 \%$ & $21.43 \%$ \\
\hline \multirow{7}{*}{ Košice region } & \multirow{7}{*}{$36.04 \%$} & \multirow{7}{*}{$100.00 \%$} & \multirow{7}{*}{$5.36 \%$} & Gelnica (GL) & $13.21 \%$ & $43.21 \%$ & $5.64 \%$ \\
\hline & & & & Sobrance (SO) & $31.92 \%$ & $70.25 \%$ & $8.64 \%$ \\
\hline & & & & Spišská Nová Ves (SN) & $28.29 \%$ & $100.00 \%$ & $5.36 \%$ \\
\hline & & & & Rožňava (RV) & $36.03 \%$ & $100.00 \%$ & $10.77 \%$ \\
\hline & & & & Košice (KE) & $36.93 \%$ & $100.00 \%$ & $5.97 \%$ \\
\hline & & & & Trebišov (TV) & $39.63 \%$ & $100.00 \%$ & $5.48 \%$ \\
\hline & & & & Michalovce (MI) & $43.05 \%$ & $100.00 \%$ & $8.05 \%$ \\
\hline \multirow{7}{*}{ Nitra region } & \multirow{7}{*}{$53.33 \%$} & \multirow{7}{*}{$100.00 \%$} & \multirow{7}{*}{$14.95 \%$} & Zlaté Moravce (ZM) & $41.10 \%$ & $71.07 \%$ & $19.29 \%$ \\
\hline & & & & Nové Zámky (NZ) & $51.55 \%$ & $100.00 \%$ & $14.95 \%$ \\
\hline & & & & Komárno (KN) & $53.87 \%$ & $100.00 \%$ & $22.49 \%$ \\
\hline & & & & Topol'čany (TO) & $53.14 \%$ & $100.00 \%$ & $28.46 \%$ \\
\hline & & & & Šal'a (SA) & $55.55 \%$ & $100.00 \%$ & $33.43 \%$ \\
\hline & & & & Leivce (LV) & $56.30 \%$ & $100.00 \%$ & $25.10 \%$ \\
\hline & & & & Nitra (NR) & $59.50 \%$ & $100.00 \%$ & $21.71 \%$ \\
\hline
\end{tabular}


Table 3. Cont.

\begin{tabular}{|c|c|c|c|c|c|c|c|}
\hline Region & $\begin{array}{l}\text { Geomean } \\
\text { TE VRS }\end{array}$ & $\begin{array}{c}\text { Max TE } \\
\text { VRS }\end{array}$ & $\begin{array}{l}\text { Min TE } \\
\text { VRS }\end{array}$ & District & $\begin{array}{l}\text { Geomean } \\
\text { TE VRS }\end{array}$ & $\begin{array}{c}\text { Max TE } \\
\text { VRS }\end{array}$ & $\begin{array}{c}\text { Min TE } \\
\text { VRS }\end{array}$ \\
\hline \multirow{13}{*}{ Prešov region } & \multirow{13}{*}{$24.41 \%$} & \multirow{13}{*}{$100.00 \%$} & \multirow{13}{*}{$2.00 \%$} & Medzilaborce (ML) & $16.85 \%$ & $52.08 \%$ & $7.60 \%$ \\
\hline & & & & Poprad (PP) & $18.46 \%$ & $46.34 \%$ & $5.77 \%$ \\
\hline & & & & Stropkov (SP) & $16.75 \%$ & $81.01 \%$ & $3.63 \%$ \\
\hline & & & & Sabinov (SB) & $21.03 \%$ & $55.20 \%$ & $3.81 \%$ \\
\hline & & & & Vranov nad Topl'ou (VT) & $26.40 \%$ & $68.28 \%$ & $6.49 \%$ \\
\hline & & & & Stará L'ubovňa (SL) & $23.55 \%$ & $69.58 \%$ & $5.06 \%$ \\
\hline & & & & Levoča (LE) & $27.29 \%$ & $69.26 \%$ & $8.04 \%$ \\
\hline & & & & Humenné (HE) & $15.91 \%$ & $100.00 \%$ & $2.00 \%$ \\
\hline & & & & Prešov (PO) & $25.79 \%$ & $100.00 \%$ & $6.19 \%$ \\
\hline & & & & Bardejov (BJ) & $29.73 \%$ & $82.89 \%$ & $6.89 \%$ \\
\hline & & & & Snina (SV) & $30.67 \%$ & $100.00 \%$ & $8.17 \%$ \\
\hline & & & & Svidník (SK) & $35.83 \%$ & $97.66 \%$ & $6.56 \%$ \\
\hline & & & & Kežmarok (KK) & $46.84 \%$ & $100.00 \%$ & $19.76 \%$ \\
\hline \multirow{9}{*}{ Trenčín region } & \multirow{9}{*}{$38.63 \%$} & \multirow{9}{*}{$100.00 \%$} & \multirow{9}{*}{$5.98 \%$} & Púchov (PU) & $20.82 \%$ & $65.66 \%$ & $5.98 \%$ \\
\hline & & & & Myjava (MY) & $28.01 \%$ & $62.34 \%$ & $11.44 \%$ \\
\hline & & & & Ilava (IL) & $30.37 \%$ & $40.41 \%$ & $17.91 \%$ \\
\hline & & & & Považská Bystrica (PB) & $32.43 \%$ & $100.00 \%$ & $8.42 \%$ \\
\hline & & & & Nové Mesto nad Váhom (NM) & $42.24 \%$ & $100.00 \%$ & $20.37 \%$ \\
\hline & & & & Bánovce nad Bebravou (BN) & $40.90 \%$ & $100.00 \%$ & $14.05 \%$ \\
\hline & & & & Prievidza (PD) & $47.67 \%$ & $89.44 \%$ & $17.66 \%$ \\
\hline & & & & Partizánske (PE) & $62.98 \%$ & $100.00 \%$ & $28.24 \%$ \\
\hline & & & & Trenčín (TN) & $61.24 \%$ & $100.00 \%$ & $32.12 \%$ \\
\hline \multirow{7}{*}{ Trnava region } & \multirow{7}{*}{$54.20 \%$} & \multirow{7}{*}{$100.00 \%$} & \multirow{7}{*}{$3.49 \%$} & Senica (SE) & $29.25 \%$ & $100.00 \%$ & $10.77 \%$ \\
\hline & & & & Piešt'any (PN) & $48.58 \%$ & $70.36 \%$ & $21.68 \%$ \\
\hline & & & & Hlohovec (HC) & $50.72 \%$ & $88.23 \%$ & $32.42 \%$ \\
\hline & & & & Dunajská Streda (DS) & $52.68 \%$ & $100.00 \%$ & $3.49 \%$ \\
\hline & & & & Skalica (SI) & $58.41 \%$ & $88.38 \%$ & $42.52 \%$ \\
\hline & & & & Trnava (TT) & $61.08 \%$ & $100.00 \%$ & $28.03 \%$ \\
\hline & & & & Galanta (GA) & $59.04 \%$ & $100.00 \%$ & $20.13 \%$ \\
\hline \multirow{11}{*}{ Žilina region } & \multirow{11}{*}{$23.98 \%$} & \multirow{11}{*}{$100.00 \%$} & \multirow{11}{*}{$2.65 \%$} & Žilina (ZA) & $13.03 \%$ & $46.08 \%$ & $2.65 \%$ \\
\hline & & & & Bytča (BY) & $17.09 \%$ & $33.06 \%$ & $9.71 \%$ \\
\hline & & & & Dolný Kubín (DK) & $22.17 \%$ & $48.13 \%$ & $7.75 \%$ \\
\hline & & & & Námestovo (NO) & $23.50 \%$ & $38.94 \%$ & $10.48 \%$ \\
\hline & & & & Liptovský Mikuláš (LM) & $22.41 \%$ & $41.71 \%$ & $10.40 \%$ \\
\hline & & & & Martin (MT) & $27.38 \%$ & $49.48 \%$ & $11.50 \%$ \\
\hline & & & & Kysucké Nové Mesto (KM) & $17.25 \%$ & $88.64 \%$ & $4.29 \%$ \\
\hline & & & & Čadca (CA) & $27.07 \%$ & $100.00 \%$ & $4.32 \%$ \\
\hline & & & & Tvrdošín (TS) & $27.68 \%$ & $100.00 \%$ & $3.51 \%$ \\
\hline & & & & Ružomberok (RK) & $28.39 \%$ & $100.00 \%$ & $12.51 \%$ \\
\hline & & & & Turčianske Teplice (TR) & $45.52 \%$ & $83.44 \%$ & $23.82 \%$ \\
\hline
\end{tabular}

The results suggest that the technical efficiency scores of the agricultural holdings in the particular regions range from $23 \%$ to $54 \%$ in 2016 and an input waste ranges from $46 \%$ to $77 \%$. The smallest technical efficiency is in the Žilina region on the north of the country where the poorest soils are concentrated and the mountain occupied the most area of the region. There are 11 districts and the district Turčianske Teplice has received the biggest technical efficiency score $(45.52 \%)$ from all districts 
in the Žilina region. However, there are also agricultural holdings in Čadca district, Tvrdošín district, or Ružomberok district where some of the agricultural holdings are effective (maximum efficiency score is $100 \%$ ). It means that it is possible to be effective also in the regions where the conditions for agricultural business are not ideal. The most efficient region is the Trnava region with the technical efficiency score $54.2 \%$. However, there is also a very big gap among its seven districts, mainly between the Senica districts and the rest of them. In spite of this fact, the Senica district is one of those where the agricultural holdings are able to be effective for $100 \%$. We can stay that the natural conditions for agriculture are not the barriers to be effective in agricultural business. The most of agricultural holdings do not know or do not want to transform inputs to effective output.

To compare the results among the regions, we use the non-parametric Kruskal-Wallis test and the multiple range tests available in Statgraphics Plus. The technical efficiency is statistically significant different among the regions (Test statistic 198.11 with the $p$-value $=0.0$ ). The multiple range tests showed that the statistically significant differences are among three groups of regions. The first one is created by the Bratislava region, the Nitra region, and the Trnava region with the best technical efficiency scores (from $49.01 \%$ to $54.2 \%$ ). The second group is created by the Košice region $(36.04 \%$ ) and the Trenčín region (38.63\%). The third group with the smallest technical efficiency scores is created by the Žilina region (23.98\%) and the Prešov region (24.41\%). Only the Banská Bystrica region (30.59\%) cannot be without doubt to include in the second or the third group. On the basis of multiple range tests (the Tukey highly significant difference (HSD) test, the Scheffe test, and the Bonferroni test), the Banská Bystrica regions should be included in the third group. However, the least significant difference (LSD) test, Duncan test, and Newmann-Keuls test are confirmed as included in the second group. We prefer to include the Banská Bystrica region in the second group on the basis of the interval classification of districts presented below. Regardless of the groups of regions, the results confirm that it is necessary to increase the technical efficiency scores of agricultural holdings in each region from $46 \%$ to $77 \%$. The results confirm that the most of the effective agricultural holdings are concentrated on the west of Slovakia. Similar results were confirmed by Bartová et al. [46] and Čechura et al. [47] that analyzed the technical efficiency of dairy farms in the Czech Republic and Slovakia on the level NUTS II. In both studies, the best technical efficiency scores of dairy farms were found in west Slovakia in comparison to Middle and East Slovakia. Bartová et al. [46] argued that the problem of inefficiency of dairy farms is related to all Slovak regions, and was mainly a result of managerial underperformance and then a non-optimal farm scale. However, Table 3 confirms that not only the districts of West Slovakia are able to be effective. Regarding the minimum and maximum values of the technical efficiency scores in Table 3, it is not possible to conclude that the technical efficiency of the agricultural holdings is more homogenous on in West Slovakia than in the other regions of the country. Therefore, we try to analyze the statistical significance differences among the districts. The technical efficiency is statistically significantly different among the districts (Test statistic 302.611 with the $p$-value $=0.0$ ). The multiple range tests showed that the statistically significant differences are between districts of Gelnica, Žilina, and Bytča on the one hand, and Senec, Malacky, Trenčín, and Partizánske on the other hand. For better visualizing the technical efficiency of agricultural holdings in the districts, we used Figure 1. We joined the districts Bratislava I to V into one district Bratislava and districts Košice I to IV and Košice-okolie into one district Košice, due to the small number of agricultural holdings in the particular districts. We have 71 districts displayed in Figure 1.

The smallest technical efficiency scores were calculated in the Žarnovica district, and the highest one was calculated in the Senec district. The districts were divided into six classes; the first class includes the districts with the most effective agricultural holdings. The classes were calculated as the share of the range (the difference between the largest and smallest values) and the number of classes. The number of classes was calculated as follows: $0.55 \times \mathrm{n}^{0.4} \leq \mathrm{k} \leq 1.25 \times \mathrm{n}^{0.4}$, where $\mathrm{n}$ is the number of the districts, and $\mathrm{k}$ is the number of classes. We chose six classes from the calculated interval $<3.026 ; 6.88>$ because of a detailed view. According to Figure 1, we can conclude that five districts have an average technical efficiency that is much higher than the average technical efficiency of the 
regions where the districts belong, and four districts have an average technical efficiency that is much lower than the average technical efficiency of the regions where the districts belong. The outliers are documented in Table 4.
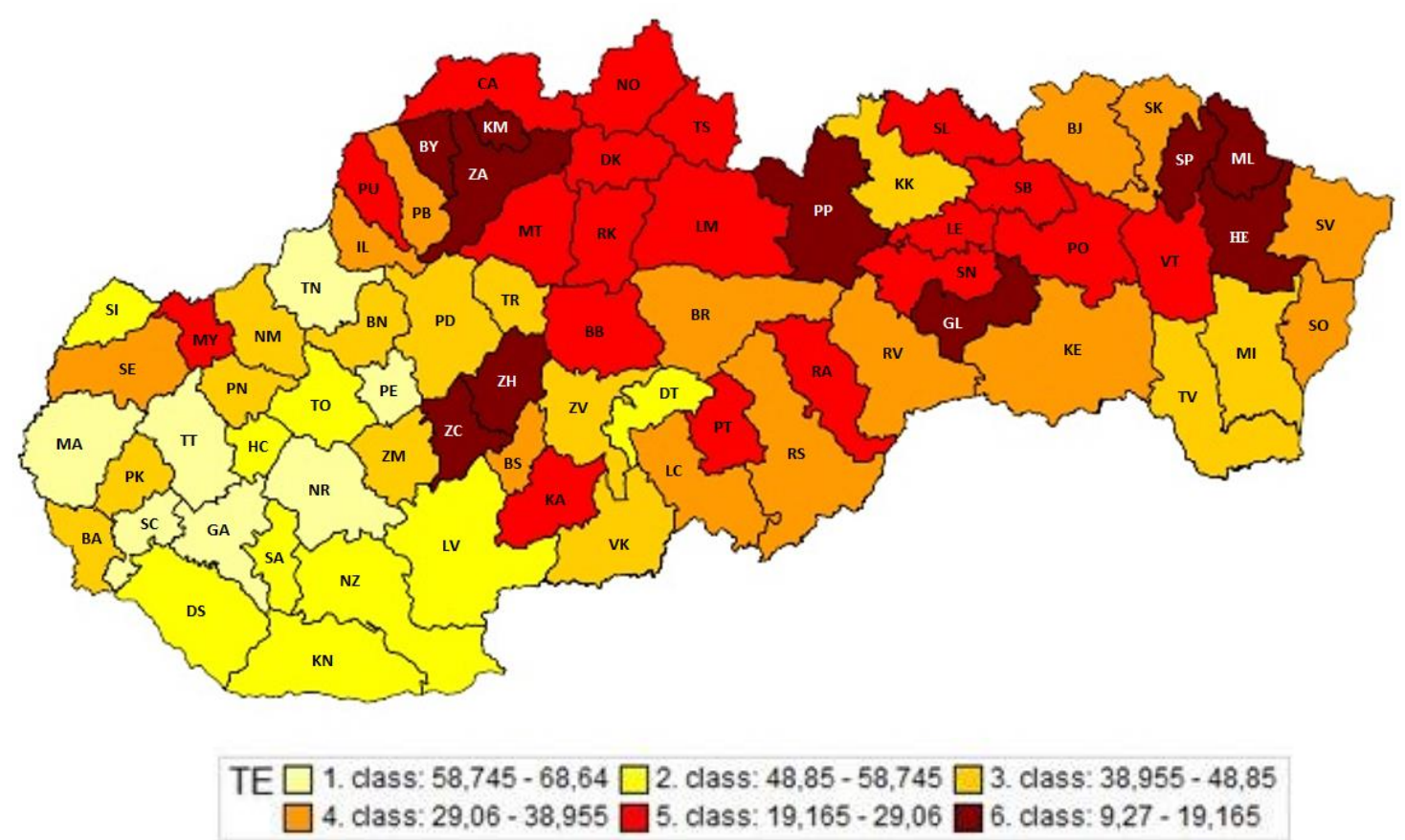

Figure 1. Technical efficiency score of agricultural holdings in the particular districts of Slovakia.

Table 4. Districts with the extreme average values of technical efficiency of agricultural holdings within the particular region.

\begin{tabular}{cccccc}
\hline \multirow{2}{*}{ Region } & Geomean & & \multicolumn{2}{c}{ Higher Values } & \multicolumn{2}{c}{ Lower Values } \\
\cline { 3 - 6 } & TE VRS & District & $\begin{array}{c}\text { Geomean } \\
\text { TE VRS }\end{array}$ & Districts & $\begin{array}{c}\text { Geomean } \\
\text { TE VRS }\end{array}$ \\
\hline \multirow{2}{*}{ The Banská Bystrica region } & $30.59 \%$ & $\mathrm{DT}$ & $49.78 \%$ & $\mathrm{ZC}$ & $9.27 \%$ \\
\cline { 3 - 6 } & & $\mathrm{x}$ & $\mathrm{x}$ & $\mathrm{ZH}$ & $16.18 \%$ \\
\hline The Bratislava region & $49.01 \%$ & $\mathrm{x}$ & $\mathrm{x}$ & $\mathrm{x}$ & $\mathrm{x}$ \\
\hline The Košice region & $36.04 \%$ & $\mathrm{x}$ & $\mathrm{x}$ & $\mathrm{GL}$ & $13.21 \%$ \\
\hline The Nitra region & $53.33 \%$ & $\mathrm{x}$ & $\mathrm{x}$ & $\mathrm{x}$ & $\mathrm{x}$ \\
\hline The Prešov region & $24.41 \%$ & $\mathrm{KK}$ & $46.84 \%$ & $\mathrm{x}$ & $\mathrm{x}$ \\
\hline The Trenčín region & $38.63 \%$ & $\mathrm{PE}$ & $62.98 \%$ & $\mathrm{x}$ & $\mathrm{x}$ \\
\hline The Trnava region & $54.20 \%$ & $\mathrm{TN}$ & $61.24 \%$ & $\mathrm{x}$ & $\mathrm{x}$ \\
\hline The Žilina region & $23.98 \%$ & $\mathrm{TR}$ & $45.52 \%$ & $\mathrm{x}$ & $\mathrm{x}$ \\
\hline
\end{tabular}

Table 4 confirms that the homogenous group of the agricultural holdings in relation to the technical efficiency scores are concentrated only in the Bratislava region and the Nitra region. Other regions received the heterogeneity of the agricultural holdings in relation to the technical efficiency scores in the particular districts that the regions include. These facts should be regarded when creating the regional policy for agriculture. Most of the regions regarding the heterogeneity of agricultural holdings in the particular districts need to take into account the special acceptation of these districts in the process of preparing the new political measures for agricultural sustainability in those districts. The results of DEA analysis enable identifying the perspective agricultural districts for agriculture as 
well as the districts with special needs. The comparison of technical efficiency differences could be a basic material for the adoption of new political measures to support sustainable agriculture in the particular districts in Slovakia.

Secondly, we expected that the heterogeneity of the technical efficiency of the agricultural holdings in the particular districts of a region is dependent on the agricultural classification of the country. We have five production areas in Slovakia:

1. maize production area (up to $200 \mathrm{~m}$ above sea level; south-west and south-east of Slovakia where most of the lowlands are situated);

2. sugar beet production area (200-300 m a.s.l.; north parts of the lowlands mentioned above);

3. potato production area (300-500 m a.s.l.; lower parts of the highlands in Middle and North Slovakia);

4. potato-oat production area (500-600 m a.s.l.; lower parts of the mountains in Middle and North Slovakia);

5. mountain production area (over $600 \mathrm{~m}$ a.s.l.; mountains region in North Slovakia).

Therefore, we expected the statistically significant differences of the technical efficiency scores among the production areas. We found out by the Kruskal-Wallis test (test statistic 154.99 with the $p$-value $=0.0$ ) and multiple range tests that there are statistically significant differences among the maize production area, sugar beet production area, and the rest of them; however, there are no statistically significant differences among the potato production area, potato-oat production area, and mountain production area. The results of technical efficiency scores are in Table 5.

Table 5. Efficiency scores of agricultural holdings in the particular production areas.

\begin{tabular}{cccc}
\hline Production Areas & Number of Agricultural Holdings & Geomean TE VRS & Standard Deviation TE VRS \\
\hline 1-maize & 610 & $47.33 \%$ & 0.2319 \\
\hline 2-sugar beet & 157 & $34.12 \%$ & 0.2614 \\
\hline 3-potato & 165 & $24.79 \%$ & 0.2436 \\
\hline 4-potato-oat & 59 & $27.43 \%$ & 0.2189 \\
\hline 5-mountain & 118 & $27.61 \%$ & 0.2502 \\
\hline
\end{tabular}

Then, we compared the results of Tables 4 and 5, and concluded that the agricultural holdings are able to be effective, regardless of the production area. Therefore, we supposed that production areas are not one of the most important factors that are able to predict the efficiency of an agricultural holding. Our hypothesis was partially confirmed by the econometric models in the further analysis.

\subsection{Factors Influencing the Technical Efficiency of the Agricultural Holdings}

Some of the scientific studies try to identify the factors of technical efficiency of agricultural holdings. Madau et al. [48] argued that differences in the technical efficiency may be caused by the structural differences among the agricultural holdings, such as the size of an agricultural holding, age of managers, climatic changes, and managerial skills. Nowak et al. [21] confirmed that the technical efficiency is positively influenced by factors such as the soil quality, the age of the head of the household, and the surcharges for investments; on the other hand, the size of the farm appeared to be irrelevant from the viewpoint of the technical efficiency of the agricultural sector. Pechrová [49] confirmed the positive and statistically significant impact of agricultural subsidies from the Programme of Rural Development on the technical efficiency of the agricultural holdings in the Czech Republic, but she added that the projects financed from the Programme of Rural Development are different, and further research of these projects on the technical efficiency of the agricultural holdings is necessary. In Slovakia, Adamišin et al. [50] analyzed the impact of legal forms of the agricultural holdings on the productivity of the agricultural holdings by the paired $t$-test, and they concluded that the business companies are able to manage an agricultural business better than the agricultural cooperatives. Moreover, 
the effective management of an agricultural holding in a worse production area is able to be a good inspiration for other agricultural holdings not only in the surroundings, but also in the better production areas. Sojková and Covaci [51] evaluated the technical efficiency by the parametric Stochastic Frontier Analysis (SFA analysis), and concluded that the agricultural holdings with the higher acreage of agricultural land are more effective. On the contrary, Fandel [38], Bielik, and Rajčániová [37] evaluated the technical efficiency by the non-parametric DEA analysis, and concluded that the most effective agricultural holdings cultivate up to 500 ha of agricultural land [37] or cultivate up to 100 ha and more than 1000 ha of agricultural land [38]. Sojková and Covaci [51] considered that the problem of different results consists in outliers and in data likelihood. Kollár and Sojková [39] confirmed the statistically significant impact of agricultural investment subsidies on the technical efficiency evaluated by SFA. However, the legal form and specialization of agricultural holdings were not confirmed as statistically significant factors. Sojková et al. [40] evaluated the technical efficiency of agricultural holdings in the production areas and ANC areas by the SFA. They found out the statistically significant differences in the technical efficiency of the agricultural holdings between the production areas and LFA areas; however, a higher variability of the technical efficiency was found among the agricultural holdings in the better production areas. On the base of a brief summary of the results from the studies of the technical efficiency of agricultural holdings, mainly in Slovakia, we tried to evaluate the impact of selected natural, geographical, social, and economic factors on the technical efficiency of the agricultural holdings by the econometric models.

Firstly, we considered as independent variables all of these variables:

- natural, production, and geographical conditions such as region, production area, distance from the city, soil quality, and agricultural production diversity expressed by the Shannon's equitability index;

- $\quad$ social conditions such as the education of managers, membership in the farmers' associations, number of members in an agricultural holding, number of new jobs, share of employees with the university education to all employees in an agricultural holding;

- legal and economic conditions such as legal form, acreage of agricultural land, average number of employees, CAP subsidies per 1 ha of land (SAPS, greening, ANC, agri-environmental scheme payments, payments for ecological agriculture, WELFARE, state subsidies, payments for the common organization of the markets, investment subsidies), share of revenues from the agricultural production in total revenues, share of revenues from the agricultural production in total costs, share of revenues from the animal production in revenues from the agricultural production, share of total revenues in total costs, share of costs for material, services, and energy in total costs, share of costs for material, services, and energy in total revenues, rent payments for 1 ha of land, share of labor costs in total costs, share of property taxes in total costs, land tax for one hectare of agricultural land, share of ANC land in the total agricultural land, and share of irrigated land in the total agricultural.

However, the models consist of the independent variables described in Table 2. Although we tried to include all above-mentioned variables, they should be excluded due to the multicollinearity of variables, heteroscedasticity of the model, or absence of the normality of residuals. We choose two models estimated by the OLS and TOBIT methods. The results are documented in Table 6. Most of the results are similar in both models; therefore, we interpreted the variables from the OLS model, and we mentioned the variable in the TOBIT model only if there is a different result. In spite of the censured variable of technical efficiency, there are no serious differences between the models. 
Table 6. OLS and TOBIT models. ANC: areas with natural constraints, AES: agri-environmental scheme payments, SAPS: single farm payment, WELFARE: payment for animal welfare.

\begin{tabular}{|c|c|c|}
\hline Variable & Model OLS & Model TOBIT \\
\hline Shannon's equitability index & $0.0691^{* * *}$ & $0.0665^{* * *}$ \\
\hline SAPS & 0.0001 & - \\
\hline Greening & 0.0001 & 0.0002 \\
\hline ANC & $-0.0007^{* * *}$ & $-0.0007^{* * *}$ \\
\hline AES & 0.0001 & 0.0001 \\
\hline WELFARE & 0.0016 & $0.0017^{*}$ \\
\hline Distance from the city & -0.0004 & -0.0003 \\
\hline Labor costs & $-0.2644^{* * *}$ & $-0.2663 * * *$ \\
\hline Total revenues share in total costs & $0.3185^{* * *}$ & $0.3209^{* * *}$ \\
\hline $\begin{array}{l}\text { Share of revenues from the animal production in } \\
\text { revenues of the agricultural production }\end{array}$ & $-0.0899 * * *$ & $-0.0964^{* * *}$ \\
\hline Number of members in an agricultural holding & 0.000006 & 0.000008 \\
\hline Number of new jobs & -0.0007 & -0.0009 \\
\hline Rent for land & 0.00005 & - \\
\hline Land taxes & $0.0025^{* * *}$ & $0.0026^{* * *}$ \\
\hline Property taxes in total costs & $-3.9346^{* * *}$ & $-4.0138^{* * *}$ \\
\hline ANC land & -0.0104 & - \\
\hline Irrigated agricultural land & 0.0806 & - \\
\hline Membership in the farmers' associations & $0.0369 *$ & $0.0386^{* *}$ \\
\hline \multicolumn{3}{|c|}{ Region } \\
\hline The Banská Bystrica region & benchmark & \\
\hline The Bratislava region & $0.0746^{* *}$ & $0.0867^{* * *}$ \\
\hline The Košice region & -0.0152 & -0.0188 \\
\hline The Nitra region & 0.0292 & 0.0363 \\
\hline The Prešov region & -0.0299 & -0.0315 \\
\hline The Trenčín region & 0.0169 & 0.0141 \\
\hline The Trnava region & 0.0513 * & $0.0587 * *$ \\
\hline The Žilina region & -0.0490 & -0.0497 \\
\hline \multicolumn{3}{|c|}{ Production areas } \\
\hline 1-maize & Benchmark & \\
\hline 2-sugar beet & -0.0346 & -0.0347 \\
\hline 3-potato & $-0.0676^{* *}$ & $-0.0673^{* *}$ \\
\hline 4-potato-oat & -0.0168 & -0.0178 \\
\hline 5-mountain & -0.0383 & -0.0394 \\
\hline Intercept & $0.1533^{* * *}$ & $0.1599 * * *$ \\
\hline R-squared & 0.3896 & - \\
\hline adjusted R-squared & 0.3625 & - \\
\hline Test of normality & $\begin{array}{c}5.5722 \\
(p \text {-value }=0.0617)\end{array}$ & $\begin{array}{c}5.7556 \\
(p \text {-value }=0.0563)\end{array}$ \\
\hline LM statistics & $\begin{array}{c}39.0934 \\
(p \text {-value }=0.0999)\end{array}$ & - \\
\hline
\end{tabular}


Agricultural production diversity is the statistically significant factor with a positive effect on the technical efficiency of the agricultural holdings. The positive regressive coefficient indicates that the technical efficiency increases with the higher agricultural production diversity. It means if the variable agricultural production diversity increases by 1 percentage point, the technical efficiency is expected to increase on average by 0.069 percentage points. This was confirmed by both models. Agricultural production diversity is one of the important factors of sustainable agriculture. Karley [4] summarized research to assess the benefits to agricultural sustainability of introducing diversity at crop, field, farm, and regional scales. In the recent years, discussions on the biodiversity conservation on agricultural land also include energy crop production [52], especially short-rotation coppice plants such as willows or poplars [53,54]. Practices that increase the diversity of crop and non-crop components of the field can contribute ecosystem services that benefit agriculture. For example, crop variety mixtures could be designed to promote the survival of rare arable plants [55]. It follows that the political measures should consider also the support of agricultural production diversity within the agricultural policy.

The second group of independent variables included in the model consists of particular subsidies of the CAP. These are statistically significant only regarding the payments for areas with natural constraints; however, the coefficient is negative one, and is close to zero. It results that the ANC payments are not an important factor of technical efficiency, although they are statistically significant coefficient. The payment for animal welfare is not statistically significant in the OLS model. In the TOBIT model, this payment was statistically significant, but only at the $p$-value of $10 \%$. The welfare payment has a positive impact on the technical efficiency; however, the coefficient is close to zero. If the welfare payment increases by 1 euro per hectare, the technical efficiency is expected to increase on average by 0.0017 percentage points. We can conclude that in general, the CAP payments do not form a statistically a significant factor regarding the technical efficiency of the agricultural holdings. Pechrová [49] arrived at a similar conclusion; she argued that on one hand, the Rural Development Programme subsidies contributed to the decrease of variance of the inefficiency term, but on the other, the effect is statistically significant only at a 90\% level of significance [49]. Kollár and Sojková [39] confirmed the statistically significant impact of agricultural subsidies on the technical efficiency evaluated by SFA, but the coefficients were negative ones. Galluzzo [56] recommended that Italian small farms smaller than 5 hectares need adequate financial supports allocated by the second pillar of the Common Agricultural Policy, and these subsides are pivotal in particular toward family farms located in the upland and hilly areas. The regression coefficients of the subsidies from the second pillar of CAP for greater farms were not statistically significant. We can conclude that the present CAP subsidies do not motivate the farmers to improve their technical efficiency. Of course, there is also the question of the distribution of subsidies. We had to exclude more than 160 agricultural holdings from the econometric model because of zero revenues from the agricultural production; however, they received the particular subsidies. On the other hand, there were smaller agricultural holdings with the revenues from the agricultural production, but they refuse the subsidies because of huge administration burden.

Other statistically significant indicators include the share of total revenues in the total costs (with the positive effect), labor costs, and property taxes in total costs (with the negative effect). The lawmaker should regard these results as very sensitive when considering the legislative amendment related to the labor market and property taxes. The share of revenues from the animal production in relation to the agricultural production revenues is one of the statistically significant factors, but with a negative effect. It means that if this variable increases by 1 percentage point, the technical efficiency is expected to decrease on average by 0.08 percentage points. The reason is that firstly, animal production needs higher costs than crop production, and secondly, most of the agricultural holdings are not able to sell their animal products with the profit: they are usually able only to cover their costs. This problem could be solved at least partially by membership in the farmers' associations. There is a positive significant effect on the technical efficiency of the agricultural holdings. It means that membership in the farmers' associations increases the technical efficiency on average by 0.03 percentage points. 
The factors such as distance from the city, number of members in an agricultural holding, number of new jobs, and rent for land are not statistically significant factors for technical efficiency. The statistically significant factor is land tax, which has a positive effect on the technical efficiency. The land tax depends significantly on the soil quality and is derived from Act no. 582/2004 Coll. on local taxes. The higher land tax means usually higher soil quality, which enables receiving an agricultural holding with a higher technical efficiency. However, the positive significant effect expressed by the coefficient is minimal (only 0.0025).

The production areas are not significant factors regarding technical efficiency in the most of the cases. The regression coefficient of production areas is statistically significant only for the potato production areas. All the regression coefficients are negative ones, regardless of statistical significance. It means that the agricultural holdings in the maize production areas have the highest technical efficiency. The agricultural holdings received the technical efficiency that was 0.068 percentage points smaller in the potato production areas than in the maize production areas. In other production areas, the regression coefficient is not statistically significant, but in spite of this fact, it is interesting that the technical efficiency decreases in the sugar beet production areas on average by 0.03 p.p., and in the potato areas on average by 0.06 p.p., but in the potato-oat production areas, the technical efficiency decreases only on average by 0.01 p.p., and in the mountain production areas, it decreases only on average by 0.03 p.p. as in the sugar beet production areas. However, we would expect that the decrease of the technical efficiency would be still higher with the higher production areas. It is possible to consider that drought and missing rainfall moves the technical efficiency from the production areas to the mountain areas. Of course, there is necessary further research to confirm this opinion, because our models do not provide a statistically significant regression coefficient.

The last factor-region (NUTS III) — was considered in the econometric models. The statistical significance was received only in the Bratislava region and the Trnava region in the TOBIT model. The Banská Bystrica region is a benchmark; then, the regression coefficients confirm that the higher technical efficiency was received in the regions of the first group (the Bratislava region, the Trnava region, and the Nitra region). The regression coefficient of the Trenčín region is positive; therefore, the technical efficiency in this region is higher than in the Banská Bystrica region, but the regression coefficient of the Košice region is negative, and the technical efficiency in this region is smaller than in the Banská Bystrica region. The Trenčín region and the Košice region were included in the second group of the regions together by the Kruskal-Wallis test and multiple-range tests, and the including of the Banská Bystrica region was not without doubt in the second or third group. Therefore, the Banská Bystrica region should be included in this group with the highest probability rather than in the third group. It follows that the location of an agricultural holding in the particular region regardless of administrative or agricultural classification is not statistically significant in favor of its technical efficiency.

\section{Conclusions}

The discussions related to the new CAP are focused on sustainable agriculture where the social, economic, and environmental objectives will be fulfilled. This role can fulfill only those agricultural holdings that are effective in the transformation of inputs to outputs, and they do not waste the inputs. The results of DEA analysis enable identifying the perspective of agricultural districts for agriculture as well as the districts with special needs. The comparison of technical efficiency differences could be a basic material for the adoption of new political measures to support sustainable agriculture in the particular districts in Slovakia. Moreover, the results proved that agricultural production diversity is one of the important factors to improve the technical efficiency of the agricultural holdings, and thus should be considered when creating the new measures of the CAP. However, not only CAP measures are important; political measures are important, too. The policy of the labor market and tax policy are also important factors that are able to influence the technical efficiency of the agricultural holdings. 
Author Contributions: Author Contributions: Conceptualization, J.L.; Methodology and software, J.L., Z.L.; Validation, L'.R., I.T.; Formal Analysis, J.L.; Investigation, L'.R., A.B.; Resources, L'.R., A.B., I.T.; Data Curation, Z.L.; Writing-Original Draft Preparation, J.L.; Writing-Review \& Editing, L'.R., I.T., Z.L., A.B.; Project Administration, L'.R.; Funding Acquisition, L'.R., A.B.

Funding: This work was supported by the Grant Agency FESRD projects no. 7/2017, "The impact of CAP supportive mechanism on the market with agricultural land in Slovakia" and Jean Monnet project no. 611792-EPP-1-2019-1-SK-EPPJMO-SUPPA, “Effectiveness of Common Agricultural Policy Implementation in Slovakia."

Conflicts of Interest: The authors declare no conflict of interest.

\section{References}

1. World Bank. Agriculture for Development. World Development Report; The World Bank: Washington, DC, USA, $2008 ; 32 p$.

2. Talukder, B.; Blay-Palmer, A. Comparison of methods to assess agricultural sustainability. In Sustainable Agriculture Reviews; Lichtfouse, E., Ed.; Springer: Cham, Switzerland, 2017; Volume 25, pp. 149-168.

3. Food and Agriculture Organisation of the United Nations. Transforming Our World: The 2030 Agenda for Sustainable Development. Resolution adopted by the General Assembly on 25 September 2015, No. A/RES/70/1. Available online: https://www.un.org/ga/search/view_doc.asp?symbol=A/RES/70/1\&Lang=E (accessed on 13 August 2019).

4. Karley, A. Utilising Diversity for Sustainable Agriculture; The James Hutton Institute: Dundee, UK, 2016; 24p.

5. Palšová, L.; Schwarcz, P. Legal regulation of direct payments in EU and Slovak Republic in programming period 2014-2020. EU Agrar. Law 2015, 4, 33-38. [CrossRef]

6. Pe'er, G.; Zinngrebe, Y.; Moreira, F.; Sirami, S.; Schindler, S.; Müller, R.; Bontzorlos, V.; Clough, D.; Bezák, P.; Bonn, A.; et al. A greener path for the EU Common Agricultural Policy. Science 2019, 365, 449-451. [CrossRef] [PubMed]

7. Roháčiková, O. Direct payments as an important tool of Common agricultural policy. In Význam a Úlohy účtovníctva a Financií v Riadenímalých a Stredných Podnikov v Pol'nohospodárstve; Slovenská pol'nohospodárska univerzita: Nitra, Slovakia, 2007; pp. 158-162.

8. European Commission. A Framework for Indicators for the Economic and Social Dimensions of Sustainable Agriculture and Rural Development; European Commission: Brussels, Belgium, 2001; 39p. Available online: https://ec.europa.eu/agriculture/publi/reports/sustain/index_en.pdf (accessed on 11 August 2019).

9. Astier, M.; García-Barrios, L.; Galván-Miyoshi, Y.; González-Esquivel, C.E.; Masera, O.R. Assessing the sustainability of small farmer natural resource management systems. A critical analysis of the MESMIS program (1995-2010). Ecol. Soc. 2012, 17, 25. [CrossRef]

10. Dong, F.X.; Mitchell, P.D.; Colquhoun, J. Measuring farm sustainability using data envelope analysis with principal components: The case of Wisconsin cranberry. J. Environ. Manag. 2015, 147, 175-183. [CrossRef] [PubMed]

11. De Koeijer, T.J.; Wossink, G.A.A.; Struik, P.C.; Renkema, J.A. Measuring agricultural sustainability in terms of efficiency: The case of Dutch sugar beet growers. J. Environ. Manag. 2002, 66, 9-17. [CrossRef]

12. Daly, H. Toward some operational principles of sustainable development. Ecol. Econ. 1990, 2, 1-6. [CrossRef]

13. Ruth, M. A quest for the economics of sustainability and the sustainability of economics. Ecol. Econ. 2006, 56, 332-342. [CrossRef]

14. Bishop, R.C. Economic Efficiency, Sustainability and Biodiversity. Ambio 1993, 22, 69-73.

15. Chebeň, J.; Lančarič, D.; Savov, R.; Tóth, M.; Tlučhoř, J. Towards Sustainable Marketing: Strategy in Slovak Companies. Amfiteatru Econ. 2015, 17, 855-871.

16. Perman, R.; Ma, Y.; McGilvray, J.; Common, M. Natural Resource and Environmental Economics; Pearson Education Limited: London, UK, 2003.

17. Charnes, A.; Cooper, W.W.; Rhodes, E. Measuring the efficiency of decision making units. Eur. J. Oper. Res. 1978, 2, 429-444. [CrossRef]

18. Galluzzo, N. A non-parametric analysis of technical efficiency in Bulgarian farms using the FADN Dataset. Eur. Countrys. 2018, 10, 58-73. [CrossRef]

19. Kočišová, K. Application of the DEA on the measurement of efficiency in the EU countries. Agric. Econ. 2015, 61, 51-62. [CrossRef] 
20. Laurinavičius, E.; Rimkuvienè, D. The Comparative Efficiency Analysis of EU Members Agriculture Sectors. Rural Sustain. Res. 2017, 37, 10-19. [CrossRef]

21. Nowak, A.; Kijek, T.; Domanska, K. Technical efficiency and its determinants in the European Union agriculture. Agric. Econ. 2015, 61, 275-283.

22. Záhorský, T.; Pokrivčák, J. Determinants of Efficiency in Agriculture in CEE Countries. In International Scientific Days 2016, The Agri-Food Value Chain: Challenges for Natural Resources Management and Society; SPU: Nitra, Slovakia, 2016; pp. 994-1001.

23. Zbranek, P.; Fandel, P. Inputové deformácie technickej zmeny v slovenskom pol'nohospodárstve v rokoch 2000-2012: Aplikácia Malmquistových indexov. Ekonomika Pol'nohospodárstva 2016, 16, 63-82.

24. Chang, C.W.; Kun-Shan, W.; Bao-Guang, C.; Kuo-Ren, L. Measuring Technical Efficiency and Returns to Scale in Taiwan's Baking Industry-A Case Study of the $85^{\circ} \mathrm{C}$ Company. Sustainability 2019, 11, 1268. [CrossRef]

25. Liu, J.S.; Lu, L.Y.; Lu, W.M.; Lin, B.J. Data envelopment analysis 1978-2010: A citationbased literature survey. Omega 2013, 41, 3-15. [CrossRef]

26. Liu, J.S.; Lu, L.Y.; Lu, W.M. Research fronts in data envelopment analysis. Omega 2016, 58, 33-45. [CrossRef]

27. Banerjee, A.; Kuri, P.K. Agricultural Growth and Regional Disparity in India: A Convergence Analysis. Sri Lankan J. Agric. Econ. 2014, 61-77. [CrossRef]

28. Barik, P. Regional Disparity in Agriculture Development and Foodavailability Status-An inter-district study of West Bengal. IOSR J. Humanit. Soc. Sci. (IOSR-JHSS) 2017, 22, 36-48.

29. Shafiqullah, D. Impact of Regional Disparities on Agricultural Development in Uttar Pradesh-A Geographical Analysis. Glob. J. Hum. Soc. Sci. Geogr. Geo-Sci. Environ. Disaster Manag. 2013, 13, 11.

30. Sharma, R. Regional Disparities in the Levels of Agricultural Development in Aligarh District of Western Uttar Pradesh. Int. J. Sci. Res. Publ. 2014, 4, 1-8.

31. Burja, V. Regional disparities of agricultural performance in Romania. Ann. Univ. Apulensis Ser. Oecon. 2011, 13, 115-121.

32. Baráth, L.; Fertő, I. Productivity and convergence in European agriculture. J. Agric. Econ. 2017, 68, $228-248$. [CrossRef]

33. Cuerva, M.C. Evolution of the agricultural productivity in the European regions: A convergence analysis with dynamic data panel methods. Economía Agraria y Recursos Naturales 2012, 12, 33-70.

34. Ezcurra, R.; Iráizoz, B.; Pascual, P.; Rapún, M. Agricultural productivity in the European regions: Trends and explanatory factors. Eur. Urban Reg. Stud. 2011, 18, 113-135. [CrossRef]

35. Marogiu, S.; Cesaro, L.; Latruffe, L.; Desjeux, Y. L’Efficienza Tecnica delle Aziende Agricole di Montagna: Analisi dei dati RICA e Confronto fra Montagna Italiana e Francese. In XXXI Conferenza Italiana di Scienze Regionali. 2010. Available online: https://aisre.it/images/old_papers/Marongiu.pdf (accessed on 28 August 2019).

36. Munroe, D. Economic Efficiency in Polish Peasant Farming: An International Perspective. Reg. Stud. 2001, 35, 461-471. [CrossRef]

37. Bielik, P.; Rajčániová, M. Efektívnost' z rozsahu pol'nohospodárskych podnikov na Slovensku. Agric. Econ. 2004, 50, 331-335.

38. Fandel, P. Technical and scale efficiency of corporate farms in Slovakia. Agric. Econ. 2003, 49, 375-383. [CrossRef]

39. Kollár, B.; Sojková, Z. Impact of the Investment Subsidies on the Efficiency of Slovak Farms. In 9th International Scientific Conference for Ph.D. Students and Young Scientists; Slezská Univerzita: Opava, Czech Republic, 2016; pp. 220-229.

40. Sojková, Z.; Kropková, Z.; Benda, V. Slovak agricultural farms in different regions-Comparison of efficiency. Agric. Econ. 2008, 54, 158-165. [CrossRef]

41. Banker, R.D.; Charnes, A.; Cooper, W.W. Models for estimation of technical and scale inefficiencies in data envelopment analysis. Manag. Sci. 1984, 30, 1078-1092. [CrossRef]

42. Shannon, C.E. A Mathematical Theory of Communication. Bell Syst. Tech. J. 1948, 27, 379-423, $623-656$. [CrossRef]

43. Lazíková, J.; Bandlerová, A.; Rumanovská, L'.; Takáč, I.; Lazíková, Z. Crop diversity and Common Agricultural Policy-The Case of Slovakia. Sustainability 2019, 11, 1416. [CrossRef]

44. Mandalová, K.; Kotrla, M.; Prčík, M. Market analysis of selected agriculture commodities cultivated on agricultural land in Slovakia regions from the perspective of sustainable development. Sci. Pap. Ser. Manag. Econ. Eng. Agric. Rural Dev. 2017, 17, 199-205. 
45. Némethová, J.; Hudáková, M. Dynamics Of Livestock Production Developement in the Slovak Republic between the years 2004 and 2017 and Potential Impact of The Changes on The Agricultural Sector And Landscape. Appl. Ecol. Environ. Res. 2019, 17, 7649-7666.

46. Bartová, L'; Fandel, P.; Košařová, J. Regional Differences in the Slovak dairy farm performance. In International Scientific Days 2018; Wolters Kluwer ČR: Praha, Czech Republic, 2018; pp. 2390-2405.

47. Čechura, L.; Hockmann, H.; Malá, Z.; Malý, M. Productivity and efficiency differences between Czech and Slovak Milk Producers. Rev. Agric. Appl. Econ. 2014, 17, 17-21.

48. Madau, F.; Furesi, R.; Pulina, P. Technical efficiency and total factor productivity changes in European dairy farm sectors. Agric. Food Econ. 2017, 5, 1-14. [CrossRef]

49. Pechrová, M. Impact of the Rural Development Programme Subsidies on the farms' inefficiency and efficiency. Agric. Econ. 2015, 61, 197-204. [CrossRef]

50. Adamišin, P.; Kotulič, R.; Vozárová Kravčáková, I. Legal form of agricultural entities as a factor in ensuring the sustainability of the economic performance of agriculture. Agric. Econ. 2017, 63, 80-92.

51. Sojková, Z.; Covaci, Š. Analýza technickej efektívnosti pol'nohospodárskych podnikov Slovenska. Acta Oeconomica Informatica 2005, 10, 1-6.

52. Dauber, J.; Miyake, S. To integrate or to segregate food crop and energy crop cultivation at the landscape scale? Perspectives on biodiversity conservation in agriculture in Europe. Energy Sustain. Soc. 2016, 6, 25. [CrossRef]

53. Demo, M.; Bako, A.; Húska, D.; Hauptvogl, M. Biomass production potential of different willow varieties (Salix spp.) grown in soil-climatic conditions of South-Western Slovakia. Wood Res. 2013, 58, 651-662.

54. Demo, M.; Hauptvogl, M.; Prčík, M.; Húska, D. Comparison of production parameters of willow (Salix spp.) and poplar (Populus spp.) varieties in the last year of the first four-year harvest cycle. Wood Res. 2014, 59, 705-715.

55. Food and Agriculture Organisation of the United Nations. Biodiversity for Sustainable Agriculture. 2018. Available online: http://www.fao.org/3/CA2227EN/ca2227en.pdf (accessed on 28 August 2019).

56. Galluzzo, N. An analysis of the efficiency in a sample of small Italian farms part of the FADN dataset. Agric. Econ. 2016, 62, 62-70. [CrossRef]

(C) 2019 by the authors. Licensee MDPI, Basel, Switzerland. This article is an open access article distributed under the terms and conditions of the Creative Commons Attribution (CC BY) license (http://creativecommons.org/licenses/by/4.0/). 